\title{
An Inventory Model with Quantity Discount Offer Policy for Perishable Goods in the Two-Level Supply Chain
}

\author{
Sasan Torabzadeh Khorasani ${ }^{\# 1}$, Maryam Almasifard ${ }^{* 2}$ \\ Industrial Engineering -Agricultural \& Applied Economics, Texas Tech University \\ 2500 Broadway, Lubbock, Texas Tech University, USA \\ ${ }^{1}$ sasan.torabzadehkhorasani@ttu.edu \\ ${ }^{2}$ m.almasifard@ttu.edu
}

\begin{abstract}
The Literature highlights the existing challenges in the supply chain management of perishable goods including the reduction of product's value over time. Reduction in quality of products leads decrease in price of products. Consequently, this circumstance results in inefficient supply chain management. One possible solution for this problem is setting a supply change management strategy with proper discount policy in order to increase the total profit. Thus, in this paper, the two-level supply chain of perishable goods, was modeled by taking into account a percent discount. The result reveal that the percentage discount equal to $6 \%$ is the optimal value in order to achieve win-win agreement between suppliers and retailers.
\end{abstract}

Keyword-Supply chain, perishable items, Discount policy, Profit

\section{Introduction and Literature Review}

Nowadays, the management of the supply chain is one of the most important fields in the business environment. Every supply chain system includes costly factors such as information, product flows, and consumption-saving decision [1], [2]. Thus, proper management of these flows will be a key to success in the supply chain. In other words, the effective management of supply chain should include efficient system design [3], and flow of goods, information and financial resources in order to maximize the profitability of the entire supply chain [4]. In fact, one of the assumptions considered in old inventory models was that all items should maintain the physical characteristics when they are stored in the warehouse [5]. Nonetheless, mass storage of perishable goods in the warehouse, especially, once they begin to lose their quality results in continuous loss or performance deterioration, corrosion damage, waste and penalties for suppliers [6]. By considering these facts, controlling and maintenance of warehouse with perishable goods is a challenging problem for decision-makers. On the other hand, the supply chain of perishable products such as food or pharmaceutical is very important because the diversity of customers in this type of supply chain is more than other systems [7]. For instance, lack of inefficient pharmaceutical supply chain results in remarkable waste of expired medication [8]. Therefore, delivering healthy goods, will increase competitiveness. A summary of conducted studies in recent years in relation to the supply chain management of perishable items is given in Table 1. Identification of characteristics related to destruction and corruptibility emerged as an interesting topic for the scholars since Pahl and his colleagues presented a model of the blood supply chain in warehouse [9]. Since then, researchers have been inspired to create and develop models for warehousing problems of perishable products in different demand levels, not only based on the items' life cycle but also with considering the type of demand which is the driving force of the entire storage system. One of the most comprehensive studies in terms of the production planning of perishable goods was conducted by Entrap [10]. Which is based on planning and scheduling systems (APS) to manage products with the short expiration date. Entrap explained how expiration date is inserted in APS common systems. He also defined special weaknesses of APS systems for perishable goods by a detailed study of the requirements and characteristics of supply chain for three different products. Based on three case studies, Entrap introduced some solutions in each APS systems that can be adopted with industry needs of new materials. 
TABLE I. The summary of recent studies of perishable good supply chain modeling

\begin{tabular}{|c|c|c|c|c|c|c|c|c|c|c|}
\hline \multirow[b]{2}{*}{ row } & \multirow[b]{2}{*}{$\begin{array}{l}\text { Researcher } \\
\text { Name }\end{array}$} & \multicolumn{8}{|c|}{ Terms of problem-solving } & \multirow[t]{2}{*}{ Solution method } \\
\hline & & Year & $\begin{array}{l}\text { Minimi } \\
\text { ze the } \\
\text { costs }\end{array}$ & $\begin{array}{l}\text { Maintena } \\
\text { nce Cost }\end{array}$ & $\begin{array}{l}\text { Shortage } \\
\text { price }\end{array}$ & $\begin{array}{c}\text { Price } \\
\text { shortages } \\
\text { caused by } \\
\text { corruption }\end{array}$ & $\begin{array}{c}\text { Time- } \\
\text { dependent } \\
\text { demand }\end{array}$ & $\begin{array}{l}\text { Perishable } \\
\text { goods }\end{array}$ & $\begin{array}{l}\text { Stairway } \\
\text { fine in the } \\
\text { delay in } \\
\text { delivery }\end{array}$ & \\
\hline 1 & $\begin{array}{c}\text { Shaabanietal. } \\
\text { [11] }\end{array}$ & 2016 & & & & & & & & $\begin{array}{c}\text { The simulation } \\
\text { algorithm based on } \\
\text { Population genetics } \\
\text { CPLEX, } \\
\text { software }\end{array}$ \\
\hline 2 & $\begin{array}{c}\text { Memariet al. } \\
{[12]}\end{array}$ & 2015 & & & & & & & & Matlab software \\
\hline 3 & $\begin{array}{c}\text { Mishra et al. } \\
{[13]}\end{array}$ & 2013 & & & & & & & & Graphics solutions \\
\hline 4 & $\begin{array}{c}\text { Ghiamiet al. } \\
{[14]}\end{array}$ & 2016 & & & & & & & & Numerical \\
\hline 5 & Feng et al. [15] & 2015 & & & & & & & & $\begin{array}{l}\text { Numerical Simulation } \\
\text { and Sensitivity } \\
\text { Analysis }\end{array}$ \\
\hline 6 & Yang et al. [16] & 2015 & & & & & & & & $\begin{array}{l}\text { mathematical } \\
\text { modeling }\end{array}$ \\
\hline 7 & $\begin{array}{c}\text { Rahdar et al. } \\
{[17]}\end{array}$ & 2014 & & & & & & & & $\begin{array}{l}\text { Mathematical models } \\
\text { and numerical solution }\end{array}$ \\
\hline 8 & $\begin{array}{c}\text { Chung et al. } \\
\text { [18] }\end{array}$ & 2013 & & & & & & & & Mathematical model \\
\hline 9 & Berk et al. [19] & 2008 & & & & & & & & Numerical \\
\hline 10 & $\begin{array}{c}\text { Kouki et al. } \\
\text { [20] }\end{array}$ & 2013 & & & & & & & & $\begin{array}{l}\text { Simulation and exact } \\
\text { solution }\end{array}$ \\
\hline 11 & Rossi et al. [21] & 2010 & & & & & & & & $\begin{array}{c}\text { Constraint } \\
\text { Programming }\end{array}$ \\
\hline 12 & Rau et al. [22] & 2003 & & & & & & & & $\begin{array}{l}\text { The economic } \\
\text { production }\end{array}$ \\
\hline 13 & $\begin{array}{c}\text { Govindan et al. } \\
{[23]}\end{array}$ & 2014 & & & & & & & & $\begin{array}{c}\text { Meta-heuristic } \\
\text { algorithm }\end{array}$ \\
\hline
\end{tabular}

Capacity planning is one of the key decisions in the production of perishable items [24], [25]. Studies carried out in this field have been focused more on agricultural products. Based[26] described the current challenges in production planning with special attention to long-term capacity investments, uncertain return and uncertain demand. He created a two-step problem as follows; the first step includes determination of capacity investment and the second step includes determination of the production quantity. Jones et al, [27]analyzed the problem of planning production that has a secondary increase in production after the initial output, which caused the uncertain returns. Jones et.al [28] analyzed the real-life capacity management problem. The profiling of demand of perishable items may be random and inconsistent due to promotional activities of the retailers, weather condition, short product life cycle, and seasonality of production [29], [21]. This inconsistency creates demand volatility in a specific period and variation in the type of uncertainty in sequential periods. Mena et.al [30] implied that demand volatility due to weather and advertisement are the main reasons in food wastes. As a result of complexity of demand volatility, the quantitative models for the inventory systems of perishable production have been created [31]. Moreover, environmental factors such as severe weather condition, lack of financing may delay manufacturing or distribution of perishable product [32], [33]. Thus, the value of items is diminished over time. To prevent loss, which is derived by value reduction of perishable items, it is assumed that the determination of a discount policy might help to design more efficient supply chain system. The discount offered by suppliers for high number of products endeavours to encourage buyers to order more products. Shin and Benton [34] offered a discount model for the supply chain including one supplier and one buyer. This model is provided as a risk analysis for the buyer that aims to increase the profit of buyer and supplier without any major changes in the economic lot sizes. The main objective of this paper is a supply chain management of perishable items using a mathematical model that can be employed as a proper tool in the management of perishable products that can improve decision making process in supply chain. The current study endeavours to provide some modifications to improve the efficiency and sustainability of supply chains of perishable items by considering the optimized lead time and discount policy. Finally, it will be endeavoured to achieve a constant desired demand which can maximize the profit for supplier and the retailer. Moreover, the impact of issuing 
policy to the retailer including First in First out (FIFO) and Last in First out (LIFO) policies will be determined on profitability of supply chain value.

\section{Mathematical model}

\section{A. Assumptions}

For the mathematical model in this study, the following assumptions are considered:

- The retailors order rate is used as a proxy for real customer demand.

- The equal lead time for both supplier and retailer is assumed [35].

- It is assumed that the items have a certain and fixed life time.

- The items will be considered as waste of the system after the end of life time, if the items are not consumed.

- It is assumed that no reduction occurred in the value of the materials during the life time.

- It is assumed that the lead time for replacement and transferring of raw material for each supplier is $\alpha$

- Another assumption is that the sorting and packaging activities to be performed quickly in the supply stage.

-The corrupted items will be replaced in the next replacement as follows: the old items of warehouse will be inspected. If their useful life has passed and there is no possibility to satisfy the order, then the cost of shortage caused by corruption will be added to the total cost. Each component in the supply chain must follow this policy for determination of the quantity of daily orders.

B. Model

\section{1) The policies for issuing FIFO and LIFO}

According to FIFO policies, seller's priority is to offer older product to buyers. If the order quantity is less than the inventory, then seller will satisfy the order by providing older items according to equation 1.

$$
S_{n . t}=\sum_{s l=1}^{s l \max } B_{n, t, s l}
$$

If the order quantity $\left(Q_{n+1, t-1}\right)$ is less than inventory $\left(I_{n, t}\right)$, the items which their remaining life are equal to 1 ,will bethrown away by considering waste handling cost. Equation 2 is representative of waste handling cost calculation.

$$
W_{n, t}=B_{n, t, s h=1}-S_{n, t}(2)
$$

On the other hand, insufficient inventory results in a sales reduction. Equation 3 is representative of sale loss.

$$
L_{n, t}=Q_{n+1, t-1}-I_{n, t}(3)
$$

According to LIFO policy, the newest items are offered to the customer. In issuing LIFO policy, if the order quantity is less than inventory $\left(I_{n, t}>Q_{n+1, t-1}\right)$, the seller will provide the order by choosing the products from the inventory by considering the process of decrease in the remaining useful life.

$$
S_{n . t}=\sum_{s l \text { max }}^{s l=1} B_{n, t, s l}(4)
$$

Equation 5 is representative of thelossesin LIFO policies.

$$
W_{n, t}=\min \left(B_{n, t, s h=1}, L_{n, t}-S_{n, t}\right)
$$

The lost sales for LIFO policy follows equation 3 likewise FIFO policy.

\section{2) The objective function}

In the decentralized supply chain, each player in supply chain systems including retailers and suppliers attempt to maximize their own profits without collaborating with the other partners. The supplier earns benefit only through deal with retailer. Therefore, registering the order $Q_{2}$ by the retailer leads the supplier earn revenue, e.g., suppliers prefer to set a discount rate for retailers. The objective function of profit for providers and retailers, respectively is 6 and 7 .

$$
\begin{aligned}
& \max \sum_{t}\left[\left(P_{1} \min \left(I_{1, t}, Q_{2} \cdot \delta_{2, t-1}\right)-\left[\delta_{1, t-L T_{1}}\left(O C_{1}+P_{0} Q_{1}\right)+H_{1} \frac{I_{1, t}}{2}+W H_{1} \cdot W_{1, t}+L S_{1} \cdot L_{1, t}+\alpha P_{1} \cdot W_{2, t}\right]\right]\right. \\
& \max \sum_{t}\left[\left(P_{2} \min \left(I_{2, t}, D_{t}\right)-\left[\delta_{2, t-L T_{2}} \cdot\left(O C_{2}+P_{1} \cdot Q_{2}\right)+H_{2} \cdot \frac{I_{2, t}}{2}+W H 2 \cdot W 2, t+L S 2 \cdot L 2, t-\alpha P_{1} \cdot W_{2, t}\right]\right]\right.
\end{aligned}
$$

\section{Where:}

$\alpha \cdot P_{1} \cdot W_{2, t}$ Discount that the supplier has considered for retailer.

$P_{1} \min \left(I_{1, t}, Q_{2} . \delta_{2, t-1}\right)$ The revenue of supplier.

$\delta_{1, t-L T_{1}} \cdot\left(O C_{1}+P_{0} \cdot Q_{1}\right)$ Thetotal cost ofpurchasing and providing of order $\mathrm{Q}_{1}$.

$H_{1} \cdot \frac{I_{1, t}}{2}$ Themaintenance cost of items in stock at time $\mathrm{t}$.

$W H_{1} . W_{1}$ The cost of waste disposal. 
$L S_{1} . L_{1, t}$ The cost of losing sales for the supplier.

$P_{2}$. min $\left(I_{2, t}, D_{t}\right)$ The revenue of retailer.

$\delta_{2, t-L T_{2}} \cdot\left(O C_{2}+P_{1} \cdot Q_{2}\right)$ The total cost of the purchase and providing order equals to $\mathrm{Q}_{2}$.

$H_{2} \cdot \frac{I_{2, t}}{2}$ The cost of maintenance items in stock at time $\mathrm{t}$.

$W_{2} \cdot W_{2, t}$ The disposal cost.

$L S_{2} . L_{2, t}$ The cost of losing sales for the retailers.

\section{Case study}

All of the provided objective functions in the previous section, have calculated long-term profit to find optimal order quantity. Thus, to evaluate the performance of the proposed model, two parameters (the number of operating days and the discount percentage) were considered. In this case study, time period of 100 days and 10 series of customer demands are considered for calculating long-term profit. It was assumed that each series of customer's demand follow the normal distribution $N \sim\left(\mu, \sigma^{2}\right)$.

Table 2 illustrates numerical values which are chosen for the parameters in our objective functions. Table 3 shows numerical values of constraints.

TABLEII. Unit prices and Costs for the supplier and retailer's objective function

\begin{tabular}{|c|c|lc|}
\hline UNIT PRICE & \multicolumn{3}{|c|}{ UNIT COSTS } \\
\hline \multirow{3}{*}{$\mathrm{P}_{0=1}$} & Inventory holding cost & Supplier & 1.005 (per day) \\
& Retailer & 1.003 (per day) \\
\cline { 2 - 4 } & Waste handling cost & Supplier & 1 \\
& Lost sales cost & Supplier & 1 \\
\hline \multirow{2}{*}{$\mathrm{P}_{1}=6$} & Retailer & 20 \\
\hline \multirow{2}{*}{$\mathrm{P}_{2=10}$} & Ordering cost & Supplier & 150 \\
& & Retailer & 100 \\
\hline
\end{tabular}

TABLEIII. Parameters for modelling

\begin{tabular}{|c|cc|}
\hline \multirow{2}{*}{ Inventory Capacity } & Supplier & 1000 units \\
& Retailer & 700 units \\
\hline \multirow{2}{*}{ Service level } & Supplier & $95 \%$ \\
& Retailer & $95 \%$ \\
\hline \multirow{2}{*}{ Lead-time } & Supplier & 2 \\
& Retailer & 1 \\
\hline \multirow{2}{*}{ Maximum remaining shelf time } & & 7 days \\
\hline \multirow{2}{*}{ Customer Demand Distribution } & & $N \sim\left(100,30^{2}\right)$ \\
\hline
\end{tabular}

\section{Result}

Before examining the impact of discounts or different issue policies, it is necessary to specify optimal order quantity for the supplier and the retailer in the decentralized supply chain. In Figure 1, averagelong-term profit in different quantity for retailer is shown., the average long-term profit of retailer and supplier are shown in different orders quantity on the basis of FIFO policy. As it is observed, the greatest amount of profitability for retailers occurs when the order quantity is 300 units. Interestingly, it can be clearly seen that the long-term profit of retailer remains constant after 350 units of orders which means that retailer can get no more benefit from selling more than 300 units since the revenue of retailer at price offers for deteriorated items will be equal to over inventory cost. On the other hand, figure 2 depicts that maximumlong-termprofit for supplier is 250 units within issuing policy of FIFO. 
After obtaining the optimal order quantity for each of the components of the supply chain, the impact of discount policy on profitability for retailers, suppliers, and the entire supply chain is studied. The advantage of considering discounts is that, firstly, the retailers are more encouraged to order goods and earns more profit. Furthermore, by offering the discount, the supplier provokes the retailers to buy more products. Consequently, the total profit of supply chain will increase.

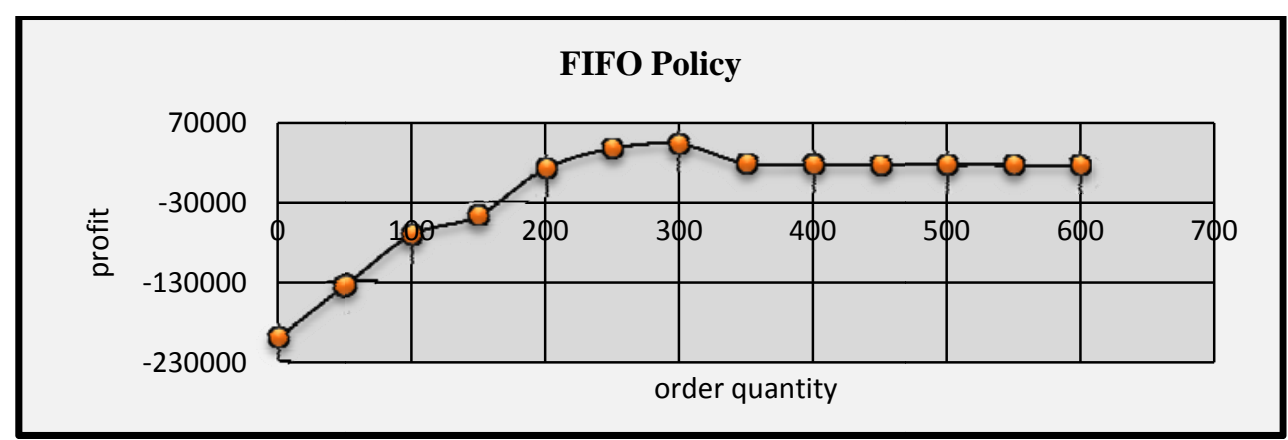

Fig.1. Average long-term profit in different order quantity for retailer

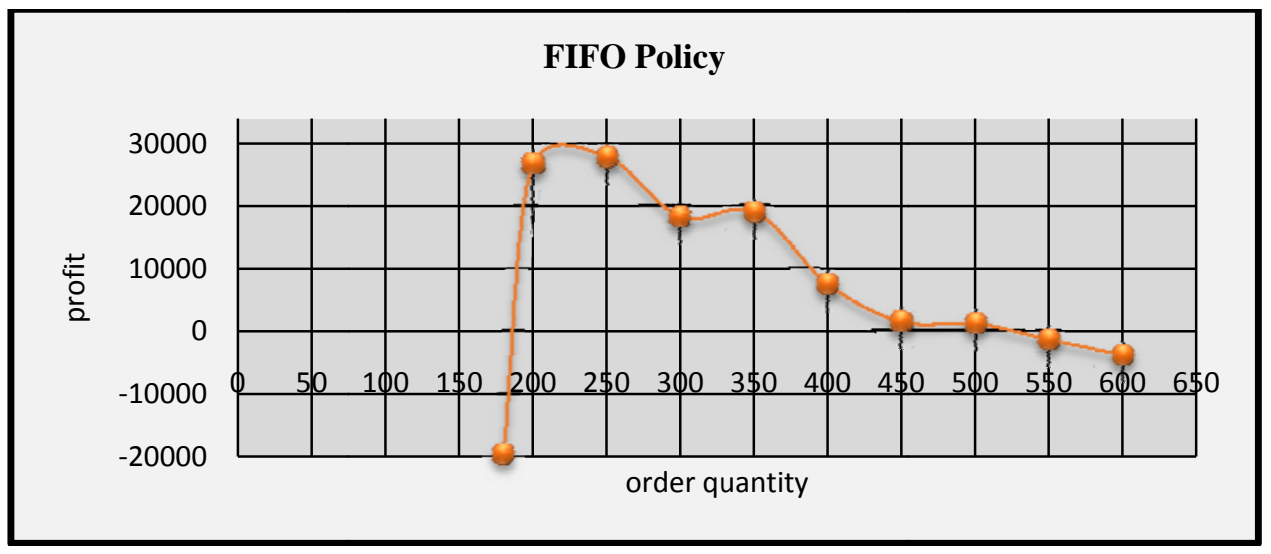

Fig. 2. Average long-term profit in different order quantity for supplier

The effect of considering the discounts is shown in Figure 3. The discount percentage has an important role in margin profit allocation between supplier and retailer. Thus, both the supplier and the retailer will be able to achieve higher profit in the long-term. In addition, the total profit of supply chain system will be increased due to the higher order quantity. As it can be clearly seen, by increasing discount rate, the profit of supplier will decrease. In contrast, the profit of retailer has incremental process. In Fig. 3, the satisfactory intervals have been considered for discount amount by following logic. The higher discount rate imposes a heavy burden on the supplier. On the other hand, the lower values cannot encourage the retailer order more.Therefore, the appropriate discount rate interval should be defined in a way that both parties can be satisfied for participating in this deal. Moreover, satisfying discount percentage can result in long term relationship between supplier and retailer. Following, Fig. 3 shows thatconsidering 2 percent discount maximizes the supplier's profit, while this rate is minimizing the long run profit obtained by the retailer. Thus, 2 percent discount cannot be satisfying rate for each supply chain party. In this case, the supplier needs to raise the discount rate till retailer becomes satisfied. On the other hand, he has to take into account that the offered discount rate should cause the least profit reduction for him. It also seems that the percentage discount equal or higher than $6 \%$ would be desirable for the retailer. Hence, satisfactory discount rate interval is identified as $6 \%$ and higher. Nonetheless, $6 \%$ discount rate results in the least profit loss for supplier. Consequently, $6 \%$ discount would be the best option that supplier can offer to the retailer. 


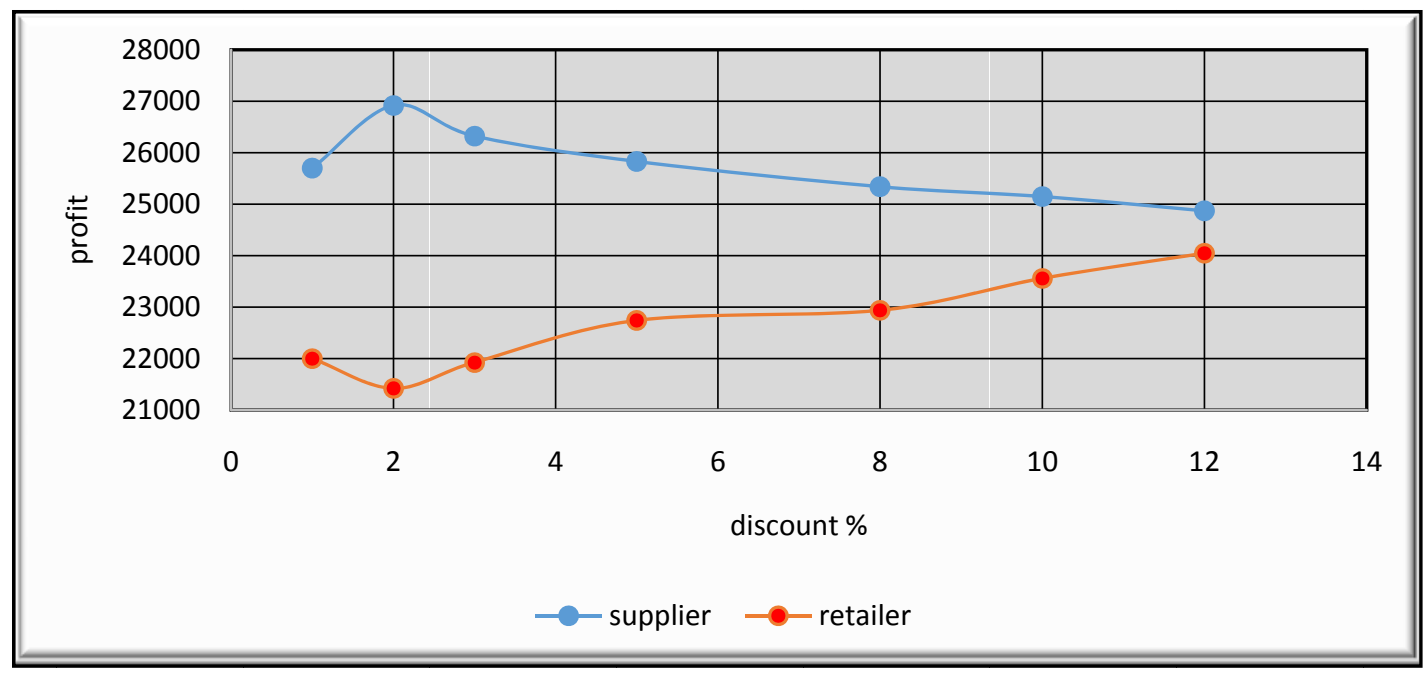

Fig. 3. Margin profit of supplier and retailer and discount percentage

\section{Conclusion}

Perishable goods supply chain islong process, difficult because of short cycle of sales, complex in terms of added value achievement, and obtain high risk of uncertaindemand. The mentioned challenges are based on the nature of the product or the preferences of the target consumer. That is improving supply chain management of perishable goods are significantly helps different stakeholders related to deteriorating items to increase their long-term profit and maintain their long-term relationship.

On the other hand, the challenge for the management of perishable products is the fact that the value of product significantly reduced overtime. For many products, a decision related to supply chain strategy involves selecting between accountability and efficiency. The right choice depends on the way how product's value changes from manufacturing to customer delivery. Therefore, by inserting discount policy not only does the supply chain can encourage retailer to do more perishable items but also it results in more trade between retailers and suppliers which will prevent corruption of mentioned items. In this paper, two-level supply chain of perishable items include one supplier-retailer with discount rate was modelled. The result of the study shows that by increasing the discount percentage, the profit of supplier in long-term diminishes and the profit of retailer increases. Finally, the overall profit of supply chain in long-term will have incremental trend. The analysis also shows that the percentage discount for $6 \%$, is the most optimal amount of discounts that can be offered by suppliers.

\section{Future work}

The finding of this study revealsa discount policy with optimized rate for supply chain of perishable goods. However, the nature of different perishable items is out of scope of this paper which can be considered in future. In other words, future research could be conducted to achieve an optimal discount policy for supply chain of perishable goods with consideration of different expiration date.

\section{References}

[1] S. Çiftçioğlu,and M.Almasifard “ The Response of Consumption to Alternative Measures of Financial Development and Real Interest Rate in a Sample of Central and East European Countries," Journal of Economics., vol . 3, pp.1-6, Jul.2015.

[2] M. Almasifard, and M.Saeedi, "Financial Development and Consumption," 2017 International Conference on Education, Economics and Management Research (ICEEMR 2017), 2017, pp.510-512.

[3] S.T .Khorasani, "Design-Driven Integrated-Comprehensive Model CDFS Strategic Relationships," in Proc.In ASME 2014 International Design Engineering Technical Conferences and Computers and Information in Engineering Conference, 2014,paper,p.V004T06A020-V004T06A020. American Society of Mechanical Engineers.

[4] E.T. Kirche, S, N. Kadipasaoglu, and B. M. Khumawala, "Maximizing supply chain profits with effective order management: integration of activity-based costing and theory of constraints with mixed-integer modelling, "International Journal of Production Research., vol43,pp.1297-1311, 2005.

[5] M.D.Hassan.Mohsen, "A framework for the design of warehouse layout," Facilities., vol.20, pp.432-440,2002.

[6] C.W.R. Lin, and H.Y.S. Chen, "Dynamic allocation of uncertain supply for the perishable commodity supply chain," International Journal of Production Research.,vol.41,pp. 3119-3138,2003.

[7] J.Wan, "Pricing Models for Perishable Goods with Customer Choice Behavior," Univ. of Electronic Science and Technology of China, Sichuan, China, 2014.

[8] S.T. Khorasani. Maghazei, and J.A. Cross, “ A STRUCTURED REVIEW OF LEAN SUPPLY CHAIN MANAGEMENT IN HEALTH CARE ," in Proc.The International Annual Conference of the American Society for Engineering Management, 2015, p. 1. American Society for Engineering Management (ASEM).

[9] J. Paul, and D. Woodruff, "Production planning with deterioration constraints: a survey. The Development of Collaborative Production and Service Systems in Emergent Economies," in Proc the 19th International Conference on Production Research. IFPR, 2007.

[10] M.L. Entrap, H.O. Gunther, P.V. Beek, M.Grunow, and T.Seiler, "Mixed-Integer Linear Programming approaches to shelf-lifeintegrated planning and scheduling in yoghurt production,’'International Journal of Production Research.,vol.43,pp.5071-5100,2005. 
[11] S. Shabani, A. Mirzazadeh, and E. Sharifi, "A two-warehouse inventory model with fuzzy deterioration rate and fuzzy demand rate under conditionally permissible delay in payment," Journal of Industrial and Production Engineering.,vol. 33,pp.134-142,2016.

[12] H. Memari, "A literature review on green supply chain modeling for optimizing CO2 emission,"Int. J. Operational Research., vol. 26, No. 4, 2016.

[13] P.K. Mishra, and B.R. Shekhr, "Consumer behaviour, customer satisfaction vis-a-vis brand performance: an empirical study of dairy food supply chain in India,"International Journal of Indian Culture and Business Management., vol.7, 2013.

[14] Y. Ghiami, and P. Beullens, "Planning for shortages? Net Present Value analysis for a deteriorating item with partial backlogging,’International Journal of Production Economics., vol.178, pp.1-11, 2016.

[15] L.Feng, J. Zhang, and W. Tang, "A joint dynamic pricing and advertising model of perishable products," Journal of the Operational Research Society., vol.66, pp.1341-1351, 2015.

[16] C.T. Yang, C.Y. Dye, and J.F. Ding, "Optimal dynamic trade credit and preservation technology allocation for a deteriorating inventory model," Computers \& Industrial Engineering. , vol.87, pp.356-369, 2015.

[17] M. Rahdar, and A.S. Nookabadi, "Coordination mechanism for a deteriorating item in a two-level supply chain system," Applied Mathematical Modelling., vol. 38, pp. 2884-2900, 2014.

[18] Y.T. Chung, and F. Erhun, "Designing supply contracts for perishable goods with two periods of shelf life," IIE Transactions., vol. 45, pp. 53-67, 2013.

[19] E.Berk, and Ü. Gürler, "Analysis of the (Q, r) inventory model for perishables with positive lead times and lost sales," Operations Research., vol. 56, pp. 1238-1246, 2008.

[20] C. Kouki, E. Sahim, E.Jemai, Z. Jemal, and Y. Dallery, "Assessing the impact of perishability and the use of time temperature technologies on inventory management,” International Journal of Production Economics., vol.143, pp.72-85, 2013.

[21] R. Rossi, S.A. Tarim, B.Hnich, and S. Prestwich, "Computing the non-stationary replenishment cycle inventory policy under stochastic supplier lead-times," International Journal of Production Economics., vol.128, pp 180-189, 2010.

[22] H.Rau, M.Y.Wu, and H.M.Wee, "Integrated inventory model for deteriorating items under a multi-echelon supply chain environment," International Journal of Production Economics., vol.86, pp. 155-168, 2003.

[23] K.Govindan, A.M Jafarian, R. Khodaverdi, and K.Devika, "Two-echelon multiple-vehicle location-Routing problem with time windows for optimization of sustainable supply chain network of perishable food," International Journal of Production Economics., vol.152, pp.9-28, 2014.

[24] M. Holweg, S.Disney, J. Holmström, and J. Småros, "Supply Chain Collaboration: Making Sense of the Strategy Continuum," European management journal. vol.23, pp.170-181, 2005.

[25] T.Boyaci, and Ö. Özer, "Information acquisition for capacity planning via pricing and advance selling: When to stop and act?," Operations Research.,vol.58,pp.1328-1349,2010.

[26] B.Kazaz, "Production Planning under Yield and Demand Uncertainty with Yield-dependent Cost and Price," Manufacturing \& Service Operations Management., vol.6, pp.209-224, 2004.

[27] P.C.Jones, T.Lowe, R.D. Traub, and J. Keller, "). Matching Supply and Demand: The Value of A Second Chance in Producing Hybrid Seed Corn," Manufacturing \& Service Operations Management., vol.3, pp.122-137, 2001.

[28] Jones, P.C., G. Keller, T. Lowe and R.D. Traub, "Managing the Seed-Corn Supply Chain at Syngenta, INTERFACES" vol.33,pp.80$90,2003$.

[29] K.G.J. Pauls-Worm, R.Rossi, R.Haijema, and J.G. A.J. van der Vorst, "computing replenishment cycle policy parameters for a perishable item with non-stationary stochastic demand under service level constraints," $24^{\text {th }}$ European conference on operational research.2010, pp.38-39.

[30] C. Mena, B. Adenso-Diaz, and O. Yurt, "The causes of food waste in the supplier- retailer interface: Evidences from the UK and Spain,” Resources, Conservation and Recycling. vol.55, pp.648-658, 2011.

[31] M. Bakker, J. Riezebos, and R.H. Tenter, "Review of inventory systems with deterioration since 2001," European Journal of Operational Research., vol.221, pp. 275-284, 2012.

[32] C.Arbib, D. Pacciarelli, and S. Smiriglio, "A three-dimensional matching model for perishable production scheduling," Discrete Applied Mathematics., vol.92, pp. 1-15,1999.

[33] M.M.Aung, and, Y.S. Chang, "Temperature management for the quality assurance of a perishable food supply chain," Food Control., vol.40, pp.198-207, 2014

[34] H.Shin, and W.C. Benton, "A quantity discount approach to supply chain coordination," European Journal of Operational Research., vol.180, pp. 601-616, 2007.

[35] M.J.Spitter, C.A.Hurkenz, A.G.DeKok, K.J. Lenstra, and E.G.Negenman, "Linear programming models with planed led time for supply chain operations planning," European journal of operational research., vol.163, pp.706-720,2005.

\section{AUTHOR PROFILE}

Sasan T Khorasani is a PhD Student and Graduate Part Time Instructor in Department of Industrial engineering at Texas Tech University. He received his Master's degree in Engineering Management from University of Politecnico di Milano. He also worked in a design-driven innovation project which was conducted by Politecnico di Milano and Cranfield University. He worked as a project manager at Bema Ettikettiertechnik GmbH (Etipack Global Network). His research interests are Supply Chain Management, Lean Methodology, Health Care Operations, Quality Management, and New Product Development. He is a member of IIE, ESTIEM, ASME, and ASEM.

Maryam Almasifardis a PhD Student and research assistant in Department of Agricultural and applied Economics at Texas Tech University. She received her master's degree in Banking and Finance from Eastern MediterraneanUniversity in Cyprus. 